\title{
MK-801 interferes with the acquisition of amphetamine- and lithium-induced place conditioning
}

\author{
JONATHAN F. TOTH and LINDA A. PARKER \\ Wilfrid Laurier University, Waterloo, Ontario, Canada
}

\begin{abstract}
The place conditioning paradigm was used to assess the ability of the noncompetitive NMDA receptor antagonist, MK-801, to interfere with drug-place associations. MK-801 (0.1 mg/kg, i.p.) attenuated a place preference produced by high, but not low to moderate, doses of amphetamine. Interference with amphetamine place preference learning was not the result of state-dependent retrieval produced by MK-801. Furthermore, MK-801 did not interfere with the expression of a previously established amphetamine place preference. Pretreatment with MK-801 also interfered with lithium-induced conditioned place aversion learning. These results suggest that the attenuation of place preference conditioning produced by MK-801 is the result of its interference with learning rather than with the rewarding properties of drugs.
\end{abstract}

The $N$-methyl-D-aspartate (NMDA) glutamate receptor plays a critical role in learning and memory processes (see, e.g., Lynch \& Baudry, 1984; Morris, Anderson, Lynch, \& Baudry, 1986; Robinson, Crooks, Shinkman, \& Gallagher, 1989). Both competitive and noncompetitive antagonists of the NMDA receptor produce deficits in acquisition of behavior indicative of olfactory conditioning (Staubli, Thibault, DiLorenzo, \& Lynch, 1989), spatial learning (Butelman, 1989; Davis, Butcher, \& Morris, 1992; Heale \& Harley, 1990; Morris et al., 1986; Shapiro \& Caramanos, 1990), conditioned fear (J. J. Kim, DeCola, Landeira-Fernandez, \& Faneslow, 1991; Miserendino, Sananes, Melia, \& Davis, 1990), extinction of conditioned fear (Falls, Miserendino, \& Davis, 1992), and conditioned taste avoidance (Welzl, Alessandri, \& Bättig, 1990). Blockade of this receptor by antagonists also impedes the induction of long-term potentiation (LTP), a physiological model that has been used to characterize learning at the synaptic level (Collingridge \& Bliss, 1987; Collingridge, Kehl, \& McLennan, 1983; Morris et al., 1986). A number of investigators have suggested that learning and memory deficits produced by NMDA antagonists may be related to the blockade of LTP (e.g., Morris et al., 1986), although this relation is a matter of controversy (e.g., Keith \& Rudy, 1990). In the present study, we

This research was supported by a research grant from the Natural Sciences and Engineering Research Council of Canada to Linda Parker (NSERC-OGP 92057). We thank Marion Corrick for maintaining the health of the animals during these experiments. We also thank Shepard Siegel for valuable discussions of the data throughout the conduct of these experiments. The amphetamine was generously supplied by NIDA. Portions of this manuscript were presented at the Conference on Comparative Cognition in Melbourne, Florida, 1997. Correspondence concerning this article should be addressed to L. A. Parker, Department of Psychology, Wilfrid Laurier University. Waterloo, ON, N2L 3C5 Canada (e-mail: Iparker@wlu.ca). investigated the potential of NMDA antagonists to modify the association produced between a place and a rewarding (amphetamine) or aversive (lithium chloride and naloxone) drug in the classical conditioning paradigm of place conditioning.

\section{MK-801 and Drug Association}

Blockade of the NMDA receptor also modifies longlasting behavioral plasticity associated with chronic drug administration, including the acquisition of tolerance to the analgesic effects of morphine (Trujillo \& Akil, 1991), as well as the sensitization to the locomotor activity effects of morphine (Jeziorski, White, \& Wolf, 1994), cocaine (Karler, Calder, Chaudhry, \& Turkanis, 1989; Pudiak \& Bozarth, 1993), and amphetamine (Karler et al., 1989; Stewart \& Druhan, 1993). The NMDA antagonist MK-801 also interferes with sensitization to the rewarding properties of cocaine in the self-administration paradigm (Schenk et al., 1993), suggesting that the disruption of NMDA function might attenuate properties of drugs that contribute to abuse liability. NMDA receptor antagonism also interferes with the establishment, but not with the expression of amphetamine-induced conditioned locomotion (Stewart \& Druhan, 1993). These findings suggest that NMDA antagonists interfere with associative learning (Popik, Layer, \& Skolnick, 1995; Trujillo \& Akil, 1991).

\section{MK-801 and Place Conditioning}

There is considerable recent evidence that MK-801 interferes with the establishment of both morphine (Clavier, Nores, Olsen, \& Vaccarino, 1996; H. S. Kim, Jang, \& Park, 1996; Tzschentke \& Schmidt, 1995) and cocaine (Cervo \& Samanin, 1995) induced conditioned place preference learning. This effect appears to be specific to the antagonism of the NMDA receptor because it is stereo- 
selective (Del Pozo, Barrios, \& Baeyens, 1996). The place conditioning paradigm is a measure of the rewarding or aversive properties of drugs (for reviews, see Carr, Fibiger, \& Phillips, 1989, and van der Kooy, 1987). With this procedure, during a training period, rats are confined to one distinctive compartment following injection of a drug, and to an alternative compartment following injection of an inert substance. Their preference for either chamber is subsequently evaluated during a test when they are undrugged and are allowed to explore both compartments. It is inferred that the drug is rewarding if the rats display a preference for the drug-paired compartment (and aversive if the rats display a preference for the alternative compartment).

There is abundant evidence that amphetamine is effective in inducing a conditioned place preference (see Carr et al., 1989; Reicher \& Holman, 1977). The strength of the preference appears to increase with amphetamine dose (Erb \& Parker, 1994; Gilbert \& Cooper, 1983; Hoffman \& Beninger, 1988; Laviola, Dell'Omo, Chiarotti, \& Bignami, 1994; Richardson et al., 1993; Spyraki, Fibiger, \& Phillips, 1982; although see Costello, Carlson, Glick, \& Bryda, 1989, and Wall, Hinson, Schmidt, Johnston, \& Streather, 1990); in fact Erb and Parker (1994) reported that the strength of an amphetamine-induced place preference increased with doses ranging from 1 to $10 \mathrm{mg} / \mathrm{kg}$, even though at the higher doses amphetamine-induced stereotypy is apparent during conditioning.

Although MK-801 interferes with morphine- and cocaine-induced place preference learning (Cervo \& Samanin, 1995; Clavier et al., 1996; H. S. Kim et al., 1996; Tzschentke \& Schmidt, 1995), it has been reported that MK-801 is ineffective in interfering with amphetamineinduced place preference learning (Hoffman, 1994). Since MK-801 does interfere with amphetamine-induced sensitization (Karler et al., 1989; Stewart \& Druhan, 1993) and conditioned locomotion (Stewart \& Druhan, 1993), it is surprising that it does not interfere with amphetamineinduced place preference learning.

The following experiments were conducted to reexamine the potential of MK-801 to interfere with amphetamine-induced place preference learning. In Experiment 1 , we evaluated the ability of MK-801 to interfere with a two-trial amphetamine- $(3 \mathrm{mg} / \mathrm{kg})$ induced place preference. Like Hoffman (1994), we found that MK-801 did not interfere with the establishment of a place preference produced by a moderate dose of amphetamine. However, in subsequent experiments, we found that when the dose of amphetamine was increased to $10 \mathrm{mg} / \mathrm{kg}$, which produced a stronger place preference, MK-801 did effectively interfere with place preference learning.

\section{EXPERIMENT 1}

In Experiment 1, we examined the ability of a low dose of MK-801 $(0.1 \mathrm{mg} / \mathrm{kg}$, i.p. $)$ to interfere with the establishment of one- or two-trial amphetamine- $(3 \mathrm{mg} / \mathrm{kg}$, i.p.) induced place preference learning. Because of contro- versial side effects of MK-801 on sensorimotor processes (Hargreaves \& Cain, 1992; Keith \& Rudy, 1990), we selected the lowest dose that has been shown to effectively modify place preferences produced by other drugs (Cervo \& Samanin, 1995; H. S. Kim et al., 1996; Tzschentke \& Schmidt, 1995). At this dose of MK-801, groups are found to be hyperactive in comparison with saline controls, but this level of hyperactivity is minimal when compared with that of groups receiving the higher doses used in the literature (Hargreaves \& Cain, 1992).

\section{Method}

Subjects. The subjects in Experiment 1 were 56 male SpragueDawley rats (Charles River Labs, Quebec) weighing 238-285 g on the 1 st day of conditioning. The rats were housed in pairs in transparent plastic cages with woodchip bedding, and they were provided with food (Lab Diet, PMI Feeds Inc.) and water ad lib. throughout the study. A 12:12-h light:dark schedule (0800-2000) was in effect in the temperature-controlled colony room $\left(21^{\circ} \pm 1^{\circ} \mathrm{C}\right)$. After 5 days of adaptation to the laboratory, the experimental procedures began. All rats were conditioned and tested at the same time of day during the light cycle.

Apparatus. The place conditioning apparatus (see Parker, 1992) consisted of four wooden shuttleboxes, each bisected into two distinctive chambers $(35 \times 25 \times 29 \mathrm{~cm})$ by four removable dividers. All chamber surfaces were painted flat black, and were identical except for floor texture $(5-\mathrm{cm}$ black sandpaper strips or $0.5-\mathrm{cm}$ wire mesh). When evaluated by group means, the preferences displayed for these chamber cues did not significantly differ when the rats were tested for $15 \mathrm{~min}$ following two pairings of each chamber with saline (mean time in sandpaper chamber, $440 \mathrm{sec}$; mean time in mesh chamber, $460 \mathrm{sec}$ ). The number of seconds spent in each chamber during the testing phase was recorded by an overhead videocamera with the signal analyzed by a video-tracking system (Videomex-V, Columbus Instruments).

Drugs. MK-801 (Research Biochemicals, Natick, MA) and $d$ amphetamine sulphate (NIDA, Research Triangle Park, NC) were dissolved in physiological saline $(0.9 \%)$ and delivered at volumes of $1 \mathrm{ml} / \mathrm{kg}$ and $2 \mathrm{ml} / \mathrm{kg}$, respectively. The dose of MK-801 was $0.1 \mathrm{mg} / \mathrm{kg}$. The amphetamine dose was $3 \mathrm{mg} / \mathrm{kg}$. All drug injections were administered i.p.

Procedure. The rats received either one $(n=32)$ or two $(n=24)$ cycles of conditioning trials prior to being tested for a place preference. A conditioning cycle consisted of a saline conditioning trial, followed $24 \mathrm{~h}$ later by an amphetamine conditioning trial. For the rats that received two conditioning cycles, the cycles were separated by $48 \mathrm{~h}$. On a saline conditioning trial, all rats received two injections of saline, spaced $30 \mathrm{~min}$ apart. Five minutes after the second injection, the rats were placed into one of the chambers (sandpaper or mesh) of the conditioning apparatus for $30 \mathrm{~min}$. On an amphetamine conditioning trial, all rats were injected with $3 \mathrm{mg} / \mathrm{kg}$ of amphetamine, 5 min prior to a 30 -min confinement in the chamber opposite to that which they experienced on the saline conditioning trial. Thirty minutes prior to the amphetamine injection, half of the rats in each group were injected with MK-801, and half of the rats in each group were injected with physiological saline.

The place preference test occurred 3 days after the final conditioning trial. During the test, the dividers were removed between the boxes, and the rats were placed at the intersection of the two chambers. The rats were allowed to explore both chambers, drug free, for a 15 -min period.

Data analysis. The data were converted to difference scores that represented the mean seconds in the amphetamine-paired chamber minus the mean seconds in the saline-paired chamber. A place preference was determined by comparing the mean difference score for 


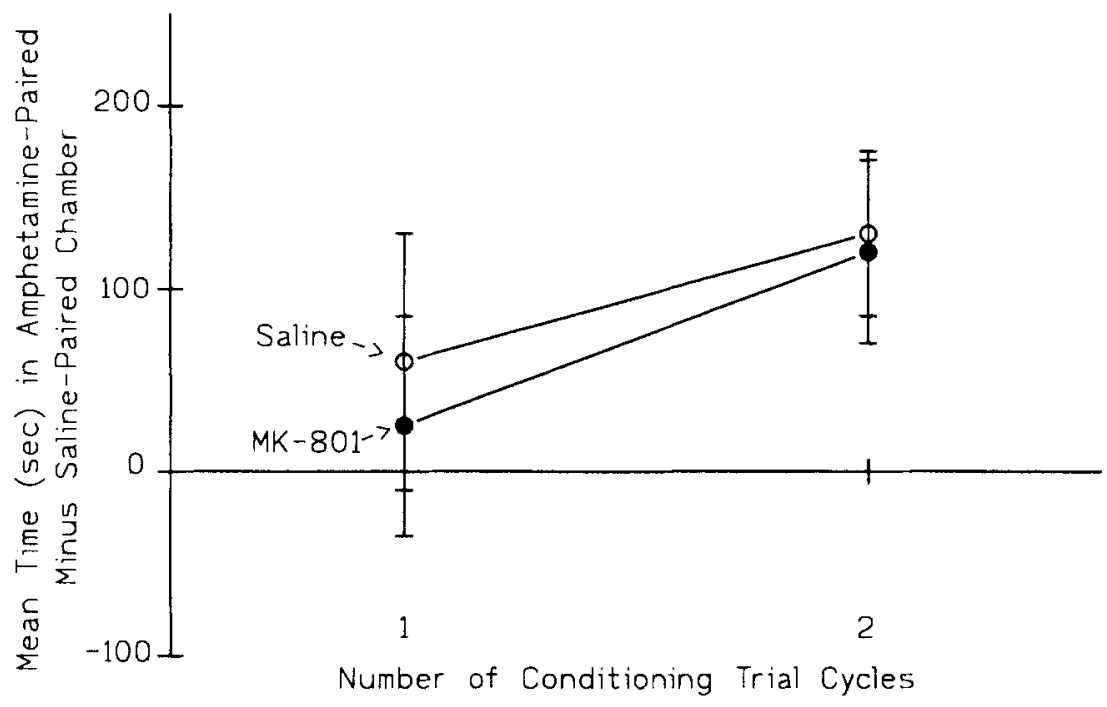

Figure 1. Mean difference scores $(+S E M)$ during the place preference test in Experiment 1 . The groups previously received one or two conditioning cycles with amphetamine $(3 \mathrm{mg} / \mathrm{kg}$ ) that were preceded by an injection of $\mathrm{MK-801}(.1 \mathrm{mg} / \mathrm{kg})$ or saline.

each group from a value of zero by means of $t$ tests. Since the side paired with amphetamine was counterbalanced, any unconditional side preferences should be equally distributed among the groups. Therefore, a zero baseline was the value expected if the rats displayed neither a place preference nor a place aversion.

\section{Results}

MK-801 did not modify the strength of an amphetamine $(3 \mathrm{mg} / \mathrm{kg})$ induced place preference following one or two conditioning trials in Experiment 1. Figure 1 presents the mean number of seconds that the rats pretreated with MK-80I or saline during one or two conditioning trial cycles spent in the amphetamine-paired chamber minus the number of seconds that they spent in the saline-paired chamber (difference score $\pm S E M$ ) during the place preference test of Experiment 1. Following two, but not one, conditioning trial cycles, rats pretreated with both MK-80I $(p<.025)$ and saline $(p<.01)$ displayed difference scores that were significantly greater than zero. However, a $2 \times 2$ between groups analysis of variance (ANOVA) with the factors of pretreatment condition (MK-801 or saline) and number of conditioning trial cycles (one or two) revealed no significant effects.

\section{Discussion}

MK- 801 did not interfere with the place preference produced by $3 \mathrm{mg} / \mathrm{kg}$ of amphetamine. These findings agree with those of Hoffman (1994), who also failed to find that MK-801 interfered with a two-trial place preference established with a relatively low dose of amphetamine $(2 \mathrm{mg} / \mathrm{kg})$.

\section{EXPERIMENT 2}

MK-801 did not interfere with the establishment of a place preference produced by a moderate dose of am- phetamine. However, an evaluation of the results of experiments in which MK-801 successfully interfered with place preference learning suggested, paradoxically, that a sufficiently strong baseline association must be established before such interference was apparent. In the studies that have demonstrated interference with place preference learning by $\mathrm{MK}-801$ pretreatment, rats received three to four conditioning trials (Cervo \& Samanin, 1995; H. S. Kim et al., 1996; Tzschentke \& Schmidt, 1995), whereas, in Hoffman's (1994) study and in Experiment 1 above, rats received only two conditioning trials with a relatively low dose of amphetamine $(2-3 \mathrm{mg} / \mathrm{kg})$. In fact, Clavier et al. (1996) have reported that MK-801 did not interfere with the acquisition of a one-trial morphine place preference, but did interfere with acquisition of a stronger two-trial morphine place preference. In Experiment 2 , the potential of MK- 801 to interfere with a twotrial place preference produced by 5 and $10 \mathrm{mg} / \mathrm{kg}$ of amphetamine was investigated. Higher doses of amphetamine produce stronger place preferences than lower doses (see, e.g., Erb \& Parker, 1994).

\section{Method}

Subjects. Ninety-three male Sprague-Dawley rats, weighing $250-270 \mathrm{~g}$ on the 1 st day of conditioning, were treated identically as in Experiment 1 except as indicated. As in Experiment 1, MK801 and $d$-amphetamine sulphate were dissolved in physiological saline $(0.9 \%)$ and delivered at volumes of $1 \mathrm{ml} / \mathrm{kg}$ and $2 \mathrm{ml} / \mathrm{kg}$, respectively. The dose of MK- 801 was $0.1 \mathrm{mg} / \mathrm{kg}$. The amphetamine dose was $5 \mathrm{mg} / \mathrm{kg}$ or $10 \mathrm{mg} / \mathrm{kg}$. All drug injections were administered i.p.

Procedure. As in Experiment 1, a conditioning cycle consisted of a saline conditioning trial followed $24 \mathrm{~h}$ later by an amphetamine conditioning trial. The two conditioning cycles were separated by $48 \mathrm{~h}$. On a saline conditioning trial, all rats received two injections of saline spaced 30 min apart. Five minutes after the second injection, the rats were placed into one of the chambers (sandpaper or mesh) of the conditioning apparatus for $30 \mathrm{~min}$. On an amphetamine 


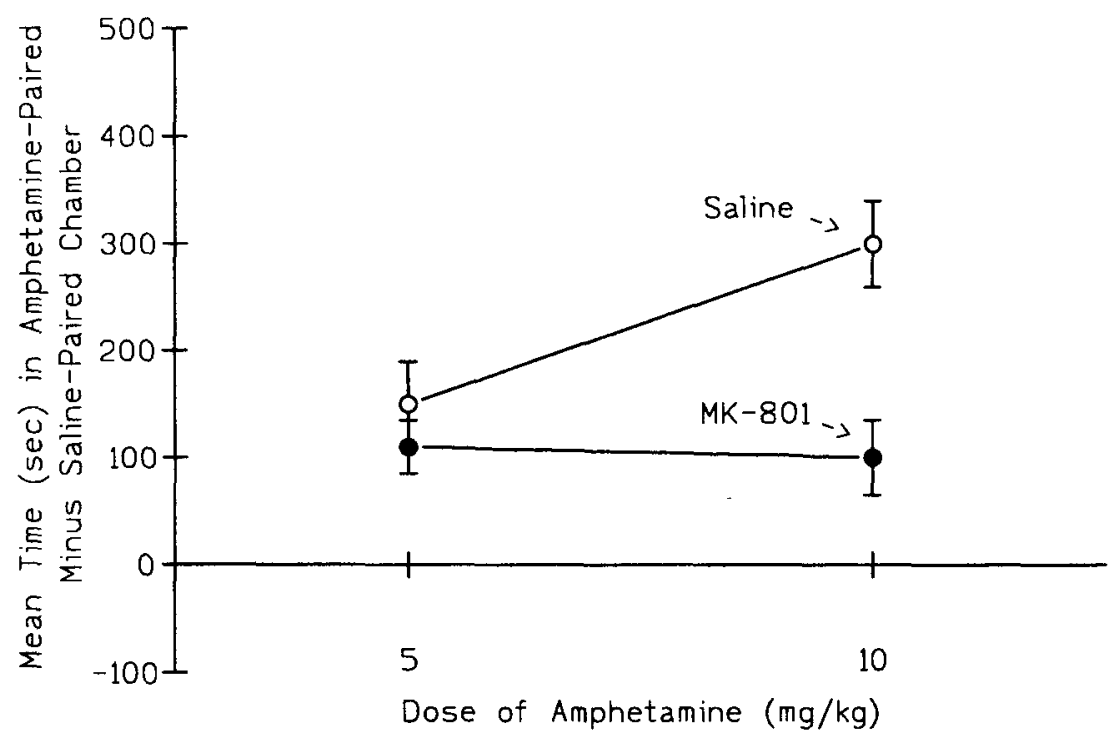

Figure 2. Mean difference scores $(+S E M)$ during the place preference test of Experiment 2. The groups received two conditioning cycles with 5 - or $10-\mathrm{mg} / \mathrm{kg}$ amphetamine that were preceded by an injection of $\mathrm{MK}-801$ or saline.

conditioning trial, rats were injected with $5 \mathrm{mg} / \mathrm{kg}(n=47)$ or $10 \mathrm{mg} / \mathrm{kg}(n=46)$ of amphetamine, $5 \mathrm{~min}$ prior to 30 -min confinement in the chamber opposite to that which they experienced on the saline conditioning trial. Thirty minutes prior to the amphetamine injection, half of the rats in each group were injected with MK-801 $(n=24)$, and half were injected with physiological saline $(n=23)$. The rats injected with $10 \mathrm{mg} / \mathrm{kg}$ of $d$-amphetamine displayed stereotyped behaviors when returned to their home cages for a number of hours on the day of conditioning. However, a period of $48 \mathrm{~h}$ intervened between the amphetamine injection and the subsequent saline trial to prevent carryover effects of the drug to the nondrug trial.

The place preference test occurred 3 days after the final conditioning trial. During the test, the dividers were removed between the boxes, and the rats were placed at the intersection of the two chambers. The rats were allowed to explore both chambers, drug free, for a 15 -min period.

\section{Results}

MK-801 interfered with the establishment of a place preference produced by $10 \mathrm{mg} / \mathrm{kg}$ of $d$-amphetamine, but not $5 \mathrm{mg} / \mathrm{kg}$ of $d$-amphetamine. Figure 2 presents the mean difference score $(+S E M)$ for the $\mathrm{MK}-801-$ and the saline-pretreated groups conditioned with 5 or $10 \mathrm{mg} / \mathrm{kg}$ of amphetamine on each of two conditioning trial cycles during the preference test of Experiment 2 . A $2 \times 2$ between-groups ANOVA with the factors of pretreatment condition (MK-801 or saline) and dose of amphetamine ( 5 or $10 \mathrm{mg} / \mathrm{kg}$ ) revealed a pretreatment condition effect $[F(1,89)=14.0, p<.01]$ and a pretreatment condition $\times$ dose interaction $[F(1,89)=5.1, p<.025]$. Subsequent Newman-Keuls pairwise comparison tests revealed that for rats conditioned at a dose of $10 \mathrm{mg} / \mathrm{kg}$ of amphetamine, but not $5 \mathrm{mg} / \mathrm{kg}$ of amphetamine, the saline-pretreated rats displayed a greater amphetamine-induced place preference than did the MK-801-pretreated rats $(p<.01)$. Furthermore, among the rats pretreated with saline, but not the rats pretreated with MK- $801,10 \mathrm{mg} / \mathrm{kg}$ of amphetamine produced a significantly greater place preference than did $5 \mathrm{mg} / \mathrm{kg}$ of amphetamine $(p<.05)$. However, MK-801 did not block the establishment of an amphetamine-induced place preference because the MK-801-pretreated groups conditioned with both 5 and $10 \mathrm{mg} / \mathrm{kg}$ of $d$-amphetamine displayed difference scores greater than zero $(p s<.05)$.

\section{Discussion}

Although MK-801 did not interfere with the establishment of an amphetamine place preference produced by 3 (Experiment 1 ) or 5 (Experiment 2) $\mathrm{mg} / \mathrm{kg}$ of $d$ amphetamine, it did attenuate the establishment of a preference produced by $10 \mathrm{mg} / \mathrm{kg}$ of $d$-amphetamine. As previously reported by Erb and Parker (1994), the salinepretreated group in Experiment 2 displayed a stronger amphetamine place preference when conditioned with $10 \mathrm{mg} / \mathrm{kg}$ of amphetamine than when conditioned with $5 \mathrm{mg} / \mathrm{kg}$. Because the strength of amphetamine place conditioning increases as the dose of amphetamine increases, it is possible that MK-801 more effectively interferes with stronger than weaker place-drug associations. In support of this suggestion, it has recently been reported that MK-801 $(0.1 \mathrm{mg} / \mathrm{kg})$ interferes with a morphine $(5 \mathrm{mg} / \mathrm{kg}$ ) place preference produced by two training trials, but not a preference produced by a single training trial (Clavier et al., 1996). Our findings suggest that Hoffman's (1994) failure to detect MK-801-induced disruption of place preference learning may have been due to the weakness of the place preference produced by $2 \mathrm{mg} / \mathrm{kg}$ of amphetamine across only two conditioning cycles. It should be noted that in other reports of MK-801-induced interference with morphine- (Del Pozo et al., 1996; H. S. 
Kim et al., 1996; Tzschentke \& Schmidt, 1995) or cocaine(Cervo \& Samanin, 1995) induced place preference learning, the rats were tested following three to four conditioning cycles.

\section{EXPERIMENT 3}

MK-801 appeared to interfere with the acquisition of an amphetamine place preference, suggesting that it interfered with learning. Conversely, the hedonic properties of MK-801 alone might contribute to its ability to interfere with place preference learning. If MK-801 is aversive (under the conditions of our findings), it would be expected to attenuate the amphetamine place preference without necessarily modifying learning. The summation of aversive properties of MK-801 and the rewarding properties of amphetamine might have prevented the establishment of an amphetamine place preference in the MK-801 pretreated groups in Experiment 2. In Experiment 3 , we evaluated the effects of MK- 801 alone administered under the same conditions as in Experiment 2.

\section{Method}

Twelve male Sprague--Dawley rats, weighing 255-265 g on the I st day of conditioning, were treated identically as in Experiment 2 except as specified. As in Experiment 2, all rats received two cycles of conditioning trials separated by $48 \mathrm{~h}$. The first trial of a cycle was a saline conditioning trial, conducted identically to that of Experiment 2 . However, on the second trial of each cycle, all rats received saline injections instead of amphetamine injections following pretreatment with $0.1 \mathrm{mg} / \mathrm{kg}$ of MK-801. A $15-\mathrm{min}$, drug-free place preference test occurred 3 days after the final conditioning trial.

\section{Results and Discussion}

MK-801 alone produced neither a place preference nor a place aversion. The mean seconds spent in the MK801 -paired chamber minus the saline-paired chamber $(-20.3 \pm 54.3 \mathrm{sec})$ did not significantly differ from a value of zero.

The attenuation of amphetamine place preference learning produced by $\mathrm{MK}-801$ cannot be attributed to the hedonic properties of MK-801 summating with those of amphetamine because MK- 801 alone produced neither a place preference nor a place aversion. In fact, other investigators have reported that when assessed under different conditions and following a greater number of training trials, MK-801 can produce a place preference at a similar dose (Layer, Kaddis, \& Wallace, 1993; Steinpreis, Kramer, Mix, \& Piwowarczyk, 1995). It is likely that, with further training, MK-801 alone would also have produced a place preference in Experiment 3. However, clearly the attenuation of amphetamine-induced place preference learning by MK- 801 is not the result of the aversive hedonic properties of MK- 801 .

\section{EXPERIMENT 4}

The results of Experiment 2 suggest that pretreatment with MK-801 attenuated the establishment of a place preference. However, an alternative explanation based on state-dependent retrieval is also possible. During conditioning, rats experienced the amphetamine-paired chambers while in an MK-801 state; however, they were tested drug free. Both the MK-801- and the saline-pretreated groups were trained with amphetamine and tested drug free. Since the saline-pretreated groups displayed a clear preference for the amphetamine-paired side, our results show that amphetamine did not produce a state-dependent deficit. However, since MK-801 has been shown to produce state-dependent retrieval (Jackson, Koek, \& Colpaert, 1992), it is conceivable that the absence of the MK-801 state during testing resulted in a state-dependent deficit in the expression of a learned preference. In fact, Carlezon, Mendrek, and Wise (1995) have recently reported that MK-801 produces state-dependent sensitization of locomotor activation by bromocriptine, although their dose of MK-801 was 2.5 times higher than that of the present investigation.

In Experiment 4, we examined the potential of statedependent retrieval to account for the interference with place preference learning produced by MK-801. If statedependent retrieval is responsible for the MK-801-induced interference with amphetamine place preference learning, rats both trained and tested in the MK-801 state should display a greater amphetamine place preference than should rats trained and tested under different states (MK801 and saline).

\section{Method}

Forty-eight male Sprague-Dawley rats weighing 235-278 g on the 1 st day of conditioning served as subjects. They were treated in a manner similar to that of Experiment 2 except as indicated. The rats received two conditioning trial cycles in which half of the rats were injected with MK-801 and half were injected with saline $30 \mathrm{~min}$ prior to the amphetamine $(10 \mathrm{mg} / \mathrm{kg})$ conditioning trial.

The place preference test occurred 3 days after the final conditioning trial. Thirty minutes prior to the test, half $(n=12)$ of the rats in each pretreatment group were injected with MK-801 $(0.1 \mathrm{mg} / \mathrm{kg}$, i.p.) and half $(n=12)$ were injected with saline.

\section{Results}

MK-801 interfered with the establishment, but not with the expression, of an amphetamine-induced place preference, and this effect was not state dependent. Figure 3 presents the mean difference scores during the place preference test of the rats pretreated with MK-801 or saline during each of the two conditioning trial cycles and tested with MK-801 or saline in Experiment 2 . A $2 \times$ 2 between-groups ANOVA revealed only a pretreatment condition effect $[F(1,44)=7.4, p<.01]$. Regardless of the test drug, rats pretreated with saline during conditioning displayed a stronger amphetamine-induced place preference than did rats pretreated with MK-801 during conditioning. MK-801 during testing did not affect the expression of the amphetamine-induced place preference.

However, MK-801 pretreatment during conditioning did not prevent the establishment of an amphetamineinduced place preference, as is evidenced by the mean 


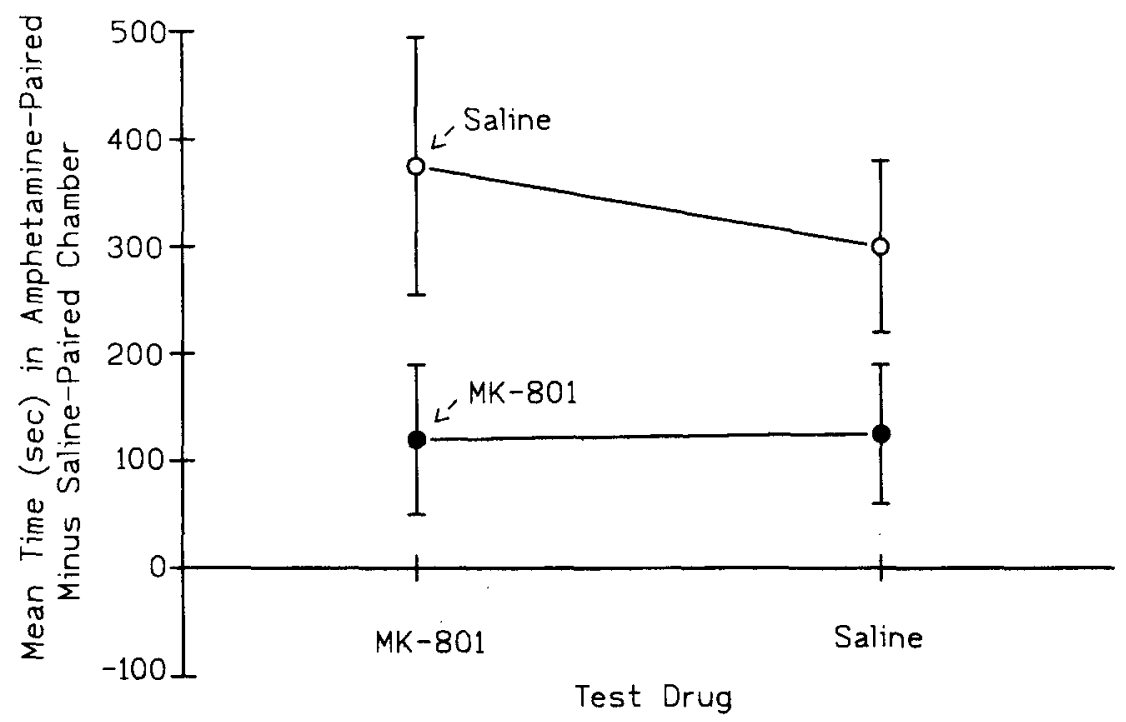

Figure 3. Mean difference scores $(+S E M)$ during the place preference test for the rats pretreated with MK-801 or saline during each of the two conditioning trial cycles and tested with MK-801 or saline in Experiment 4.

difference scores of rats pretreated with MK-801 during conditioning which were greater than a value of zero, regardless of whether they were tested following injections of MK-801 or saline $(p \mathrm{~s}<.05)$.

\section{Discussion}

Consistent with the results of Experiment 2, Experiment 4 demonstrated that MK-801 interfered with the establishment of amphetamine-induced place preference learning. This effect was probably not the result of statedependent retrieval, because it was not modulated by the drug state in which the rats were tested. If interference by MK-801 was due to state-dependent retrieval, rats conditioned and tested in the MK-801 state should have displayed a greater place preference than did the rats conditioned in the MK-801 state and tested in the saline state. This pattern of results did not occur. However, although amphetamine alone did not produce a statedependent deficit in place preference learning in the saline-pretreated group, it remained possible that the state produced by the combined MK-801 and amphetamine might have produced a state-dependent learning deficit.

In this experiment, we also assessed the ability of MK801 to interfere with the expression of a previously established amphetamine-induced place preference. The rats that were trained in a saline state, but tested in an MK801 state, assessed the potential of MK-801 to interfere with the display of a previously learned place preference. Clearly, MK-801 did not interfere with the expression of a place preference produced by $10 \mathrm{mg} / \mathrm{kg}$ of amphetamine, although it did attenuate the establishment of that preference. This finding is consistent with others in the literature suggesting that MK-801 interferes with the establishment, but not with the expression of learning (e.g.,
J. J. Kim et al., 1991; Shapiro \& Caramanos, 1990; Stewart \& Druhan, 1993).

\section{EXPERIMENT 5}

The attenuation of place preference learning produced by MK-801 might be the result of MK-801-induced interference with the rewarding properties of the conditioning drug or might be the result of MK-801-induced interference with learning. If MK-801 should interfere with the acquisition of drug-place associations rather than with reward, it would interfere not only with place preference learning, but also with place aversion learning. Indeed, Higgins, Nguyen, and Sellers (1992) reported that MK-801 $(0.1 \mathrm{mg} / \mathrm{kg})$ attenuated the establishment of a conditioned place aversion produced by naloxoneprecipitated morphine withdrawal. In Experiment 5, we assessed the ability of MK-801 to interfere with the establishment of a conditioned place aversion produced by lithium chloride $(\mathrm{LiCl})$.

\section{Method}

The subjects were 24 male Sprague-Dawley rats weighing $240-290 \mathrm{~g}$ on the $1 \mathrm{st}$ day of conditioning. The procedures of Experiment 5 were similar to those of Experiment 2, except that the conditioning drug was $\mathrm{LiCl}$ ( 75 or $127 \mathrm{mg} / \mathrm{kg}$ of a $0.15 \mathrm{M}$ solution), instead of amphetamine. On each of two conditioning trial cycles, rats received saline trials on Monday and Thursday; they were injected i.p. with $1 \mathrm{ml} / \mathrm{kg}$ of saline $30 \mathrm{~min}$ prior to another i.p. injection of either $12(n=12)$ or $20(n=12) \mathrm{ml} / \mathrm{kg}$ of saline, 5 min prior to placement in the appropriate chamber for $30 \mathrm{~min}$. They received the drug conditioning trial on Tuesday and Friday. On each trial, they were injected i.p. with either saline or MK-801 $(0.1 \mathrm{mg} / \mathrm{kg}) 30 \mathrm{~min}$ prior to an i.p. injection of either 12 or $20 \mathrm{ml} / \mathrm{kg}$ of $0.15 \mathrm{M} \mathrm{LiCl}, 5 \mathrm{~min}$ prior to placement in the alternate chamber for $30 \mathrm{~min}$. Three days after the final conditioning trial, they were given a $15-\mathrm{min}$ place preference test. 


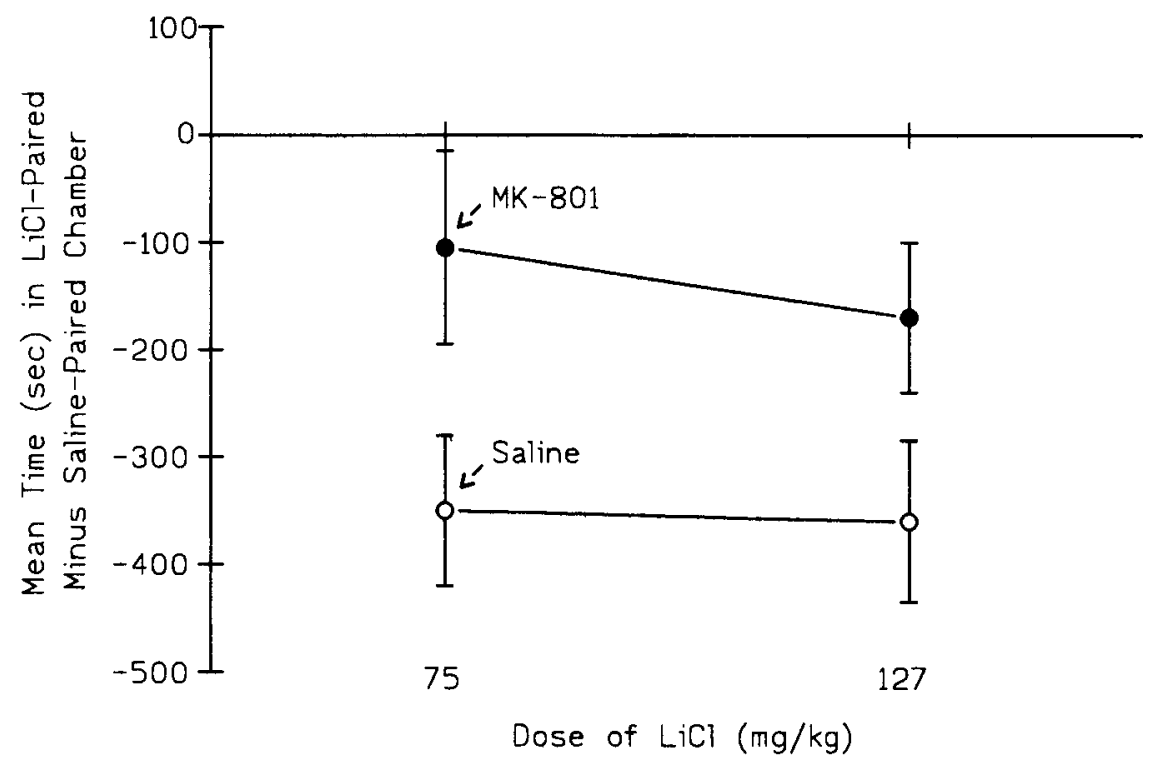

Figure 4. Mean difference scores $(+S E M)$ during the preference test of Experiment 5 . The groups were pretreated with $\mathrm{MK-801}$ or saline during the two conditioning cycles with $\mathrm{LiCl}$ ( 75 or $127 \mathrm{mg} / \mathrm{kg}$ ).

\section{Results}

MK-801 interfered with the establishment of a place aversion produced by $\mathrm{LiCl}$. Figure 4 presents the mean seconds in the LiCl-paired minus the saline-paired chamber for the rats pretreated with MK-801 or saline during conditioning with either 75 or $127 \mathrm{mg} / \mathrm{kg}$ of $\mathrm{LiCl}$. A $2 \times$ 2 between-groups ANOVA revealed only a pretreatment condition effect $[F(1,20)=4.5, p<.05]$. MK-801 interfered with, but did not eliminate, a LiCl-induced aversion; that is, the mean difference scores of the MK-801 pretreated group conditioned with $127 \mathrm{mg} / \mathrm{kg}$ of $\mathrm{LiCl}$, but not $75 \mathrm{mg} / \mathrm{kg}$ of $\mathrm{LiCl}$, were significantly less than zero $(p \mathrm{~s}<.05)$.

\section{Discussion}

MK-801 attenuated the establishment of a place aversion produced by 75 or $127 \mathrm{mg} / \mathrm{kg}$ of $\mathrm{LiCl}$. The NMDA antagonist appears to interfere with learning processes in general because it interferes with the establishment of place preference learning produced by amphetamine, morphine (Clavier et al., 1996; H. S. Kim et al., 1996; Tzschentke \& Schmidt, 1995), and cocaine (Cervo \& Samanin, 1995), as well as with place aversion learning produced by lithium and naloxone-precipitated morphine withdrawal (Higgins et al., 1992).

\section{GENERAL DISCUSSION}

When administered at a low dose, MK-801 interferes with the establishment of a lithium-induced conditioned place aversion and an amphetamine-induced conditioned place preference. This effect appears to be the result of interference with learning, because MK-801 did not modify the expression of a previously established amphetamineinduced conditioned place preference. Furthermore, the decrement in place preference learning was not the result of MK-80l-induced state dependent learning.

Paradoxically, it appears that the efficacy of MK-801 to attenuate amphetamine place preference learning is reliant on a sufficiently strong baseline association. In the present study, MK-801 interfered with a two-trial place preference established with a dose of $10 \mathrm{mg} / \mathrm{kg}$ of amphetamine, but did not interfere with a weaker place preference established with doses of 3-5 $\mathrm{mg} / \mathrm{kg}$ of amphetamine. These findings agree with those of Hoffman (1994), who also failed to find that MK-801 attenuated a two-trial place preference established with a relatively low dose of amphetamine $(2 \mathrm{mg} / \mathrm{kg})$. It should be noted that in other instances of MK-801-induced interference with morphine- or cocaine-induced place preference learning, the rats received three to four pairings of the drug with the chamber (Cervo \& Samanin, 1995; Del Pozo et al., 1996; H. S. Kim et al., 1996; Tzschentke \& Schmidt, 1995). Furthermore, Clavier et al. (1996) reported that MK-801 did not interfere with the acquisition of a morphine place preference after one conditioning trial, but that it did attenuate the place preference produced after the second conditioning trial (which strengthened the association).

The attenuation of amphetamine-induced place preference learning does not appear to be simply the result of MK-801-induced state-dependent retrieval. In Experiment 4, we examined the strength of a place preference in rats tested under the influence of MK-801 or saline. If the attenuation of an amphetamine-induced place preference in rats treated with MK-801 during conditioning 
was the result of state-dependent retrieval (see, e.g., Carlezon et al., 1995), the preference should have been greater when the rats were tested in the same MK-801 state that they experienced during conditioning. This did not occur. The only effect that was apparent in Experiment 4 was that the animals pretreated with MK-801 during conditioning displayed a weaker amphetamine place preference than did the animals pretreated with saline during conditioning, regardless of the drug condition under which the rats were tested. Although amphetamine alone did not produce a state-dependent deficit in the saline-pretreated rats, it does remain possible that the combined MK-801 and amphetamine state distinctively produced a statedependent deficit.

The results of Experiment 4 also indicate that MK-801 selectively interfered with the acquisition of amphetamine-induced place preference learning, but not with the expression of a previously learned place preference. This finding is consistent with others in the literature (e.g., J. J. Kim et al., 1991; Shapiro \& Caramanos, 1990; Stewart \& Druhan, 1993), suggesting that antagonism of NMDA receptors may selectively interfere with learning.

Although the dose of MK-801 used in the present experiments was low, there is some evidence in the literature that this dose modifies activity levels in rats (Hargreaves \& Cain, 1992), although it is near the threshold for such effects. One might argue that nonspecific sensorimotor deficits produced during conditioning interfered with the ability of rats to form the association between amphetamine or lithium and the chamber. However, if such is the case, one must also explain why these sensorimotor deficits selectively affected the establishment of an association between the context and amphetamine in the groups conditioned with $10 \mathrm{mg} / \mathrm{kg}$ of amphetamine, but not in the groups conditioned with $3-5 \mathrm{mg} / \mathrm{kg}$ of amphetamine, as well as the context and lithium in Experiment 4. Furthermore, if sensorimotor deficits produced by MK-801 interfered with the ability of rats to form an association during conditioning, one might expect such deficits to also interfere with the ability of rats to display the established association when administered prior to a place preference test. However, MK-801 did not modify the expression of an amphetamine-induced place preference in Experiment 2.

MK-801 could disrupt the establishment of place preference learning produced by amphetamine, morphine (Del Pozo et al., 1996; H. S. Kim et al., 1996; Tzschentke \& Schmidt, 1995), and cocaine (Cervo \& Samanin, 1995) by interfering with learning or by interfering with the drug-induced reward. Because MK-801 interferes with the establishment of a place aversion produced by lithium (Experiment 3 ) and naloxone-precipitated morphine withdrawal (Higgins et al., 1992), it is most likely that MK-801 directly modifies the place cues-drug association. In fact, there is evidence that MK- 801 actually potentiates responding maintained by cocaine (Ranaldi,
French, \& Roberts, 1996) and by brain stimulation reward (Corbett, 1989; Herberg \& Rose, 1989), as well as the ability of both morphine (Carlezon \& Wise, 1993) and cocaine (Ranaldi, Bauco, \& Wise, 1996) to enhance brain stimulation reward in operant tasks. Unlike place conditioning, these paradigms assess the ability of MK801 to maintain steady state responding of a behavior that is already learned. MK-801 does not appear to interfere with drug-induced reward.

In contrast, place conditioning, on the other hand, measures the ability of drugs to establish a preference or aversion to a place. Therefore, this paradigm assesses the ability of MK-801 to interfere with the acquisition of a learned preference or aversion. Because MK-801 interfered not only with amphetamine-induced place preference learning, but also with lithium-induced place aversion learning, it appears to interfere with learning processes rather than with reward.

\section{REFERENCES}

Butelman, E. R. (1989). A novel NMDA antagonist, MK-801, impairs performance in a hippocampal-dependent spatial learning task. Pharmacology, Biochemistry \& Behavior, 34, 13-16.

Carlezon, W. A., Jr., Mendrek, A., \& Wise, R. A. (1995). MK-801 disrupts the expression but not the development of bromocriptine sensitization: A state-dependency interpretation. Synapse, 20, 1-9.

Carlezon, W. A., JR., \& Wise, R. A. (1993). Morphine-induced potentiation of brain stimulation reward is enhanced by MK-801. Brain Research, 620, 339-342.

Carr, G. D., Fibiger, H. C., \& Phillips, A. G. (1989). Conditioned place preference as a measure of drug reward. In J. M. Liebman \& S. J. Cooper (Eds.), The neuropharmacological hasis of revard (pp. 264-319). Oxford: Oxford University Press, Clarendon Press.

Cervo, L., \& Samanin, R. (1995). Effects of dopaminergic and glutamatergic receptor antagonists on the acquisition and expression of cocaine conditioning place preference. Brain Research, 673, 242250.

Clavier, M. C.. Nores, W. L.. Olsen, R. D., \& Vaccarino. A. L. (1996). NMDA antagonist, MK-801, antagonizes the development of morphine-induced conditioned place preference. Society for Neuroscience Abstracts, 22, 174.

Collingridge, G. L., \& Bliss, T. V. P. (1987). NMDA receptors: Their role in long-term potentiation. Trends in Neurosciences, 10, 288-294.

Collingridge, G. L., Keht, S. J.. \& McLennan, H. (1983). Excitatory amino acids in synaptic transmission in the Shaffer-collateralcommissural pathway of the rat hippocampus. Journal of Phvsiologv. 334, 33-46.

Corbert, D. (1989). Possible abuse potential of the NMDA antagonist MK-801. Behavioural Brain Research, 34, 239-246.

Costello, N. L., Carlson, J. N., Glick. S. D. \& Bryda, M. (1989). Dose-dependent and baseline-dependent conditioning with $d$ amphetamine in the place conditioning paradigm. Psychopharmacology, 99, 244-247.

Davis, S., Butcher, S. P., \& Morris, R. G. M. (1992). The NMDA receptor antagonist D-2-amino-5-phosphopentanoate (D-AP5) impairs spatial learning and LTP in vivo at intracerebral concentrations comparable to those that block LTP in vitro. Journal of Neuroscience, 12 , 21-24.

Del Pozo, E., Barrios, M., \& Baeyens, J. M. (1996). The NMDA receptor antagonist dizocilpine (MK-801) stereoselectively inhibits morphine-induced place preference conditioning in mice. Psychopharmacology, 125, 209-213.

Erb, S. M., \& Parker, L. A. (1994). Individual differences in novelty- 
induced activity do not predict strength of amphetamine-induced place conditioning. Pharmacology, Biochemistry \& Behavior, 48, 581-586.

Falls, W. A., Miserendino, M. J. D.. \& Davis, M. (1992). Extinction of fear-potentiated startle: Blockade by infusion of an NMDA antagonist into the amygdala. Journal of Neuroscience, 12, 854-863.

Gilbert, D., \& CoOper, S. J. (1983). Beta-phenylethylamine, $d$ amphetamine and $l$-amphetamine-induced place preference conditioning in rats. European Journal of Pharmacology, 95, 311-314.

Hargreaves, E. L., \& CaIN, D. P. (1992). Hyperactivity, hyper-reactivity, and sensorimotor deficits induced by low doses of the $N$-methyl-Daspartate non-competitive channel blocker MK-801. Behavioural Brain Research, 47, 23-33.

Heale, V., \& HarLey, C. (1990). MK-80I and AP5 impair acquisition but not retention of the Morris milk maze. Pharmacology, Biochemistry \& Behavior, 36, 145-149.

HerberG, L. J., \& Rose, I. C. (1989). The effect of MK-801 and other antagonists of NMDA-type glutamate receptors on brain-stimulation reward. Psychopharmacology, 99, 87-90.

Higgins, G. A., Nguyen, P., \& Sellers, E. M. (1992). The NMDA antagonist dizocilpine (MK-801) attenuates motivational as well as somatic aspects of naloxone precipitated opioid withdrawal. Life Sciences, 50, PL167-PL172.

HoFFman, D. C. (1994). The noncompetitive NMDA antagonist MK801 fails to block amphetamine-induced place conditioning in rats. Psvchopharmacologv, Biochemistrv \& Behavior, 47, 907-912.

Hoffman, D. C., \& Beninger, R. J. (1988). Selective D1 and D2 dopamine agonists produce opposing effects in place conditioning but not in conditioned taste aversion learning. Pharmacology, Biochemistry \& Behavior, 31, 1-8.

JACKSON, A., KOEK, W., \& COLPAERT, F. C. (1992). NMDA antagonists make learning and recall state-dependent. Behavioural Pharmacologv, 3, 415-421.

Jezionski, M., White, F. J., \& Wolf, M. E. (1994). MK-801 prevents the development of behavioral sensitization during repeated morphine administration. Synapse, 16, 137-147.

Karler, R., Calder, L. D.. Chaudhry, I. A., \& Turkanis, S. A (1989). Blockade of "reverse tolerance" to cocaine and amphetamine by MK-801. Life Sciences, 45, 599-606.

KeITH, J. R., \& RudY, J. W. (1990). Why NMDA-receptor-dependent long-term potentiation may not be a mechanism of learning and memory: Reappraisal of the NMDA-receptor blockade strategy. Psychobiology, 18, 25I-257.

KIM, H. S., JANG, C. G., \& PARK, W. K. (1996). Inhibition by MK-801 of morphine-induced conditioned place preference and postsynaptic dopamine receptor supersensitivity in mice. Pharmacology, Biochemistry \& Behavior, 55, 11-17.

Kim, J. J., DeCola, J. P., Landeira-Fernandez, J., \& Fanselow, M. S. (1991). $N$-methyl-D-aspartate receptor antagonist APV blocks acquisition but not expression of fear conditioning. Behavioral Neuroscience, 105, 126-133.

layiola. G., Dellomo, G., Chiarotti, F., \& Bignami, G. (1994). $d$ Amphetamine conditioned place preference in developing mice: Relations with changes in activity and stereotypies. Behavioral Neuroscience, 108, 514-524.

Layer, R. T., KadDis, F. G.. Wallace, L. J. (1993). The NMDA receptor antagonist MK-801 elicits conditioned place preference in rats. Pharmacology, Biochemistry \& Behavior, 44, 245-247.

LynCH, G., \& BAUDRY, M. (1984). The biochemistry of memory: A new and specific hypothesis. Science, 224, 1057-1063.

Miserendino, M. J. D., Sananes, C. B., Melia. K. R., \& Davis, M. (1990). Blocking of acquisition but not expression of conditioned fear-potentiated startle by NMDA antagonists in the amygdala. $\mathrm{Na}$ ture, 345, 716-718.

Morris, R. G., ANDERson, E., Lynch, G. S., \& Baudry. M. (1986). Selective impairment of learning and blockade of long-term-potentiation by an $N$-methyl-D-aspartate receptor antagonist, AP5. Nature, 319 , 774-776.
PARker, L. A. (1992). Place conditioning in a three- or four-choice apparatus: Role of stimulus novelty in drug-induced conditioning. $B e$ havioral Neuroscience, 106, 294-306.

Popik, P., LAYER, R. T., \& SKOLNICK, P. (1995). 100 years of ibogaine: Neurochemical and pharmacological actions of a putative antiaddictive drug. Pharmacological Reviews, 47, 235-253.

Pudiak, C. M., \& BozarTh, M. A. (1993). L-NAME and MK-801 attenuate sensitization to the locomotor-stimulating effect of cocaine. Life Sciences, 53, 1517-1524

Ranaldi, R.. Bauco, P., \& Wise, R. A. (1996). Synergistic effects of cocaine and dizocilpine (MK-801) on brain stimulation reward. Society for Neuroscience Abstracts, 22, 935.

Ranaldi, R., French, E., \& Roberts, D. C. S. (1996). Systemic pretreatment with MK-801 (dizocilpine) increases breaking points for self-administration of cocaine on a progressive-ratio schedule in rats. Psychopharmacology, 128, 83-88.

Reicher, M. A., \& Holman. E. W. (1977). Location preference and flavor aversion reinforced by amphetamine in rats. Animal Learning \& Behavior, 5, 343-346.

Richardson, N. R., Piercey, M. F., Svensson, K., Collins, R. J., MYERS, J. E., \& RoBERTS, D. C. (1993). Antagonism of cocaine selfadministration by the preferential dopamine autoreceptor antagonist, (+)-AJ 76. Brain Research, 619, 15-21.

Robinson, G. S., Jr., Crooks, G. B., Jr., Shinkman, P. G., \& GalLAGHER, M. (1989). Behavioral effects of MK-801 mimic deficits associated with hippocampal damage. Psychobiology, 17, 156-164.

Schenk. S., Valadez, A., McNamara, C., House, D. T., Higley, D., Bankson, M. G., GibBs, S., \& Horger, B. A. (1993). Development and expression of sensitization to cocaine's reinforcing properties: Role of NMDA receptors. Psychopharmacology, 111, 332-338.

Shapiro, M. L., \& Caramanos, Z. (1990). NMDA antagonist MK-801 impairs acquisition but not performance of spatial working and reference memory. Psychobiology, 18, 231-243.

Spyraki, C., Fibiger, H. C., \& Phillips, A. G. (1982). Dopaminergic substrates of amphetamine-induced place preference conditioning. Brain Research, 253, 185-193.

Staubli, U., Thibault, O.. Dilorenzo. M., \& Lynch, G. (1989). Antagonism of NMDA receptors impairs acquisition but not retention of olfactory memory. Behavioral Neuroscience, 103, 54-60.

Steinpreis, R. E., Kramer, M. A., Mix, K. S., \& Piwowarczyk, M. C. (1995). The effects of MK-801 on place conditioning. Neuroscience Research, 22, 427-430.

Stewart, J., \& Druhan, J. P. (1993). Development of both conditioning and sensitization of the behavioral activating effects of amphetamine is blocked by the noncompetitive NMDA receptor antagonist, MK-801. Psychopharmacology, 110, 125-132.

TRUjILLO, K.A., \& AKIL, H. (1991). Inhibition of morphine tolerance and dependence by the NMDA receptor antagonist MK-801. Science, 251, 85-87.

TzSchentKe, T., \& Schmidt, W. J. (1995). $N$-methyl-D-aspartic acidreceptor antagonists block morphine-induced conditioned place preference in rats. Neuroscience Letters, 193, 37-40.

VAN DER KOOY, D. (1987). Place conditioning: A simple and effective method for assessing the motivational properties of drugs. In M. A. Bozarth (Ed.). Methods of assessing the reinforcing properties of abused drugs (pp. 229-240). New York: Springer-Verlag.

Wall, A.-M., Hinson, R. E., Schmidt, E., Johnston, C., \& Streather, A. (1990). Place conditioning with $d$-amphetamine: The effect of CS-UCS interval and evidence of a place avoidance. Animal Learning \& Behavior, 18, 393-400.

Welzl, H., Alessandri, B., \& BätTiG, K. (1990). The formation of a new gustatory memory trace in rats is prevented by the noncompetitive NMDA antagonist ketamine. Psychobiology, 18, 43-47.

(Manuscript received January 18, 1999; revision accepted for publication July 19, 1999.) 